ENGLISH GRAMMAR FOR TODAY:

A NEW INTRODUCTION 


\section{English Grammar for Today}

A new introduction

Geoffrey Leech

Margaret Deuchar

Robert Hoogenraad

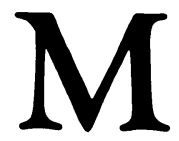

THE MACMILLAN PRESS

in conjunction with

Macmillan Education 
(C) Geoffrey Leech, Margaret Deuchar, Robert Hoogenraad 1982

Softcover reprint of the hardcover 1st edition 1982

All rights reserved. No part of this publication may be reproduced or transmitted, in any form or by any means, without permission.

First published 1982 by

THE MACMILLAN PRESS LTD

London and Basingstoke

Companies and representatives throughout the world

ISBN 978-0-333-30644-4 ISBN 978-1-349-16878-1 (eBook)

DOI 10.1007/978-1-349-16878-1

Typeset in Great Britain by

MULTIPLEX TECHNIQUES LTD, ORPINGTON, KENT

The paperback edition of this book is sold subject to the condition that it shall not, by way of trade or otherwise, be lent, re-sold, hired out, or otherwise circulated without the publisher's prior consent in any form of binding or cover other than that in which it is published and without a similar condition including this condition being imposed on the subsequent purchaser. 


\section{Contents}

Foreword

$\mathrm{ix}$

Preface

Symbols and conventions

$\mathrm{xi}$

xiv

PART A: INTRODUCTION

1 What grammar is and is not

1.1 Grammar and its role in language 3

1.2 'Good' and 'bad' grammar 5

1.3 Variation in language 6

1.4 English and other languages 10

$\begin{array}{ll}1.5 & \text { Grammar and effective communication } \\ 1.6 & 12\end{array}$

1.6 Grammar in prose style 13

1.7 Grammar in poetry 15

$\begin{array}{lll}1.8 & \text { Conclusion } & 16\end{array}$

Exercises $\quad 17$

PART B: ANALYSIS

2 Sentences and their parts

2.1 Prologue: parts of speech 23

2.2 The hierarchy of units 26

2.3 Grammatical notations 28

2.4 Using tests 30

2.5 Form and function 32

2.6 Summary 36

Exercises $\quad 37$

3 Words 41

3.1 Open and closed word classes 41

3.2 The open classes 43

3.3 Closed word classes $\quad 50$

3.4 Summary and conclusion $\quad 54$

Exercises $\quad 55$ 
4 Phrases

4.1 Classes of phrase $\quad 57$

4.2 Main and subordinate phrases 58

4.3 Noun phrases and related phrase classes 60

4.4 The adjective phrase and the adverb phrase 65

4.5 The verb phrase 66

$\begin{array}{lll}4.6 & \text { Summary } & 70\end{array}$

Exercises $\quad 71$

5 Clauses

5.1 Elements of the clause

5.2 Complex sentences 75

5.3 Finite and non-finite clauses 77

5.4 Declarative, interrogative and imperative 78 $\begin{array}{ll}\text { clauses } & 79\end{array}$

\begin{tabular}{ll}
5.5 & Active and passive clauses \\
\hline
\end{tabular}

5.6 More on clause structure $\quad 82$

5.7 Clause patterns $\quad 84$

5.8 The structure of non-finite clauses 86

5.9 Parsing a simple sentence $\quad 87$

5.10 Summary 91

Exercises $\quad 91$

6 Subordination and coordination

6.1 Subordinate clauses 93

6.2 Finite subordinate clauses 96

6.3 The functions of subordinate clauses 100

6.4 Non-finite subordinate clauses 101

6.5 Direct and indirect subordination 103

6.6 Skeleton analysis 105

6.7 Coordination 107

6.8 Summary and conclusion 109

Exercises $\quad 111$

7 Basic and derived structures

7.1 Constituent structure grammar 113

7.2 Basic and derived structures 114

7.3 'Missing' elements 116

$\begin{array}{lll}7.4 & \text { Split constituents } & 119\end{array}$

$\begin{array}{ll}7.5 \text { 'Double analysis' } & 120\end{array}$

$\begin{array}{lll}7.6 & \text { Back to parsing } & 123\end{array}$ 
7.7 Style and transformations

7.8 Summary and conclusion

\section{PART C: APPLICATIONS}

8 Discourse analysis: speech and writing
8.1 Introductory
8.2 Speech and writing: which comes first?
8.3 Functions of writing and speech
8.4 The form of speech and writing
8.5 Linguistic characteristics of speech and writing
8.6 Analysis of spoken and written discourse
8.7 Conclusion
Exercise

9 Discourse analysis: tenor and domain

9.1 Introductory

9.2 Tenor

9.3 Tenor and discourse

9.4 Domain

9.5 Domain and discourse

9.6 Combining categories of use

Exercise

10 Analysis of literary discourse

10.1 How to analyse style

10.2 Illustrative extract

10.3 Outline analysis

10.4 Further illustrative extracts for discussion

Exercises

11 Grammar and problems of usage

11.1 Opinions about grammar

11.2 Prescriptive 'rules'

11.3 The priests of usage

11.4 The problem of personal pronouns

11.5 The problem of number concord

11.6 The problem of the generic masculine

11.7 Problems of ellipsis 
viii CONTENTS

11.8 Dangling non-finite clauses $\quad 180$

11.9 Conclusion 181

Exercises $\quad 182$

12 Grammar and composition

12.1 Grammar and writing

12.2 'Make your language easy to follow' 184

12.3 'Be clear' 190

12.4 'Be economical' 191

12.5 'Be clear but concise': clarity versus economy

192

12.6 'Be effective' 193

Exercises 195

Answers to exercises 199

Further reading $\quad 215$

$\begin{array}{ll}\text { Index } & 218\end{array}$ 


\section{Foreword}

Voices in the English Association have been urging for some time that the moment is ripe for a new English grammar for use in schools, colleges and universities and the Association has been fortunate in bringing together three authors whose distinction and expertise eminently qualify them for the task and a publisher long established in the field.

It is probably true to say that not many years ago such a book could hardly have attracted a publisher, for two very good reasons.

The climate of opinion has for long been unfavourable to giving grammatical teaching to native speakers of English. From causes that we need not go into here, the old tradition of school grammar waned. Grammar for foreign learners was acknowledged to be unavoidable; the rest of us could manage without. And so, of course, many of us did; and perhaps we felt the language survived quite happily when we did not look too closely, whether as teachers or as students or as general users of the language, at the imprecision, the incoherence and - let us confess it - often the incomprehensibility of much of what we read or even wrote in our everyday lives.

A second reason was severely practical. It is, after all, not long since Professor Randolph Quirk complained of the absence of any sound criterion by which to establish what really was acceptable English: 'the writer of a teaching grammar is ... at the grammatical level ... almost entirely without a body of descriptive data, and so ... he has to rely largely on a hesitant and uncertain introspection into his own usage or his intuitive knowledge'.

That the situation has changed is due in great measure to Professor Quirk and his colleagues in the Survey of English Usage, at University College, London, and to its daughter project at the University of Lancaster, where Professor Leech and his colleagues are investigating

1 Randolph Quirk, comment in an article reprinted in his Essays on the English Language: Medieval and Modern (London: Longman, 1968) p. 110. 
present-day English with the aid of the computer. By far the most important achievement of this new emphasis on the study of English grammar through its usage in the language is surely the monumental Grammar of Contemporary English, ${ }^{1}$ which is widely regarded as authoritative.

'Authoritative', like the word 'authority', is likely to raise hackles, and so it is proper to point out that it is authoritative statements of the facts of English today that are in question, not rules as to how we should or should not express ourselves. Rules there will be, based on unquestionable fact, but often it is a matter rather of grades of acceptability. We believe there is now a growing body of opinion eager for direction of this kind.

We hope that English Grammar for Today will serve as a valuable tool for students, however little their knowledge of grammatical terms, and also for teachers, whether inclined more to a traditional or a modern approach, who believe that a return to a vigilant and well-informed attitude towards the language they use and love is long overdue.

The English Association is grateful to the authors for the care they have given to the preparation of this book, and to those of its members and of its Executive Committee who read earlier drafts and contributed suggestions for improvement. Further suggestions from readers will be welcomed.

\section{GEOFFREY HARLOW \\ Chairman, Publications Subcommittee, The English Association, 1 Priory Gardens, Bedford Park, London, W4 1TT}

1 By Randolph Quirk, Sidney Greenbaum, Geoffrey Leech and Jan Svartvik (London: Longman, 1972). 


\section{Preface}

This is an introductory course in English grammar for use in Englishmedium schools, colleges and universities. Lamentably, there is at present no recognised place for English grammar in the British educational curriculum. In fact it is still possible for a student to end up with a degree in English at a British university without having cause to know the first thing about English grammar, or the grammar of any other language. But if we are right in supposing that the time is right for a revival of the subject in schools, there will be a growing need for introductory courses at various levels. Thus this book has a multiple purpose. It is primarily designed as a course book for students at the upper secondary level (sixth forms) and the tertiary level (colleges, polytechnics, universities), but it is also adapted to the needs of teachers interested in exploring a new approach to grammar, or of any person keen to catch up with a subject so wretchedly neglected by our educational system.

If grammar is to become a vital subject in the English curriculum, we have to exorcise finally the spectre of Browning's grammarian who

Gave us the doctrine of the enclitic $D e$

Dead from the waist down

(Robert Browning, The Grammarian's Funeral)

That spectre still haunts our collective consciousness in the form of a Victorian schoolmaster instilling guilty feelings about split infinitives and dangling participles, and vague fears that grammar may prove to be nothing else than hacking the corpses of sentences to pieces and sticking labels on the resulting fragments. That is why some of this book is devoted to the correcting of preconceptions. Part A, 'Introduction', is meant to provide a reorientation: dispelling myths, and seeking a new appraisal of the value of grammar in present-day education. Part B, 'Analysis', is the main part of the book, presenting a method for describing the grammatical structure of sentences. Part C, 'Applications', shows 
how this method of analysis can be used in the study of style in its broadest sense, and in the development of written language skills.

The system of grammatical analysis introduced in Part B is influenced by the systemic grammar of M. A. K. Halliday, and more directly by that found in Randolph Quirk et al., A Grammar of Contemporary English (1972), and its adaptations in Quirk and Greenbaum, $A$ University Grammar of English (1974) and Leech and Svartvik, $A$ Communicative Grammar of English (1975). It is a framework which has been widely adopted in the study of English by non-native speakers, making informal use of modern developments in linguistics, but not departing without good reason from traditional terms and categories which are to some extent a common cultural heritage of the Western world. Naturally the framework has had to be considerably simplified. 'Grammar', for our purpose, is defined in a narrow sense for which nowadays the term 'syntax' is sometimes used. It means roughly 'the rules for constructing sentences out of words', and it excludes, strictly speaking, the study of what words and sentences mean, and how they are pronounced.

Exercises are provided at the end of each chapter, but their function in each Part is somewhat different. For Part A the exercises are merely an encouragement towards thinking on new lines about grammar. In Part B the exercises are much more fully integrated into the learning process; it is important for students to test their progress in understanding the system by doing the exercises where indicated. In part $\mathrm{C}$ the exercises in Chapters 8-10 invite the student to try out the system of grammatical analysis on different styles and varieties of English. Here grammar will be seen in relation to other levels of language, such as meaning and vocabulary, as part of the total functioning of language as a communication system.

The book can be used as a course book, each chapter providing one or two weeks' work, though the exercises are varied in form and purpose. Some exercises consist of problems with more or less definite answers, and in these cases answers are given at the back of the book (pp.199-214). Other exercises are open-ended tasks to which no answers can be given. The exercises which have answers provided are so indicated by the cross-reference 'answers on p. 00' alongside the heading. Thus those using the book for private study will gain some feedback, while teachers using the book as a course book will find enough material for week-by-week preparation and discussion, in addition to the exercises which students may check for themselves.

Following the Answers to Exercises, we list books and articles for Further Reading (on pp.215-17). The list is alphabetical, and on the few occasions in the text where we need to refer to one of the works listed, references are given by the author's name, the title, and the date of 
publication: e.g. 'Crystal, Linguistics, 1971'. It would be impossible to give due credit to grammarians and other scholars whose work and ideas have influenced this book directly or indirectly; where such ideas have become part of the currency of present-day linguistics, we make no attempt to do so.

Although the book does not include a glossary of technical terms, the function of such a glossary can be matched by careful use of the Index, in which technical terms of grammar are listed alphabetically, together with the pages on which they are introduced and explained.

We thank Martin McDonald for providing us with the material quoted on pp. 151, 153, 155-6.

We owe a general debt to the English Association, which provided the impetus and opportunity for the writing of this book, and a more particular debt to the Chairman of its Publications Subcommittee, Geoffrey Harlow, and to other members of the Association, especially Raymond Chapman, who have given us encouragement and detailed guidance.

Lancaster

GEOFFREY LEECH

August 1981

MARGARET DEUCHAR

ROBERT HOOGENRAAD 


\section{Symbols and conventions}

The sections where the symbol or convention is first introduced, and where the grammatical category is most fully discussed, are here shown in brackets.

\section{Labels}

\section{Function labels}

$\begin{array}{llll}A & \text { Adverbial }(2.5 .3 ; 5.1 .3) & M v & \text { Main verb }(2.5 .3 . ; 4.5) \\ \text { Aux } & \text { Auxiliary verb }(2.5 .3 ; & O & \text { Object }(2.5 .2 ; 5.1 .2) \\ & 4.5) & O d & \text { Direct object }(5.6) \\ C & \text { Complement }(2.5 .3 ; 5.1 .2) & O i & \text { Indirect object }(5.6) \\ C o & \text { Object complement }(5.6) & P & \text { Predicator }(2.5 .2 ; 5.1 .1) \\ C S & \text { Subject complement } & S & \text { Subject }(2.5 .2 ; 5.1 .1) \\ & (3.2 .3 ; 5.6) & V o c & \text { Vocative }(5.6) \\ H & \text { Head }(2.5 .3 ; 4.1) & & \\ M & \text { (Pre- or post-) modifier } & & \\ & (2.5 .3 ; 4.1) & & \end{array}$

Form labels

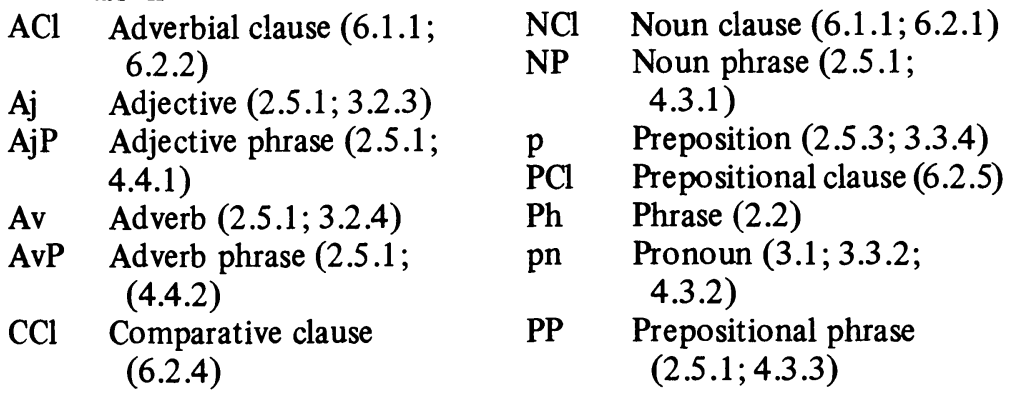


cj (Subordinating or coordinating) conjunction $(3.1 ; 3.3 .5)$

$\mathrm{Cl}$ Clause (2.2) (for Cli, Cling, Clen, see below)

d Determiner $(3.1 ; 3.3 .1$; 4.3.2)

e $\quad$ Enumerator $(3.1 ; 3.3 .3)$

GP Genitive phrase (2.5.1; 4.3.4)

ij Interjection $(3.1 ; 3.3 .7)$

$\mathrm{MCl}$ Main clause (5.2)
$\mathrm{N} \quad$ Noun $(2.5 .1 ; 3.2 .1)$

$\mathrm{RCl}$ Relative clause (6.2.3)

-'s Genitive marker (4.1; 4.3.4)

$\mathrm{SCl}$ Subordinate clause $(5.2 ; 6.1)$

Se Sentence (2.2)

V Verb $(2.5 .1 ; 3.2 .2)$ (used for full-verb or operatorverb)

v Operator-verb $(3.1 ; 3.3 .6)$

VP Verb phrase $(2.5 .1 ; 4.5)$

Wo Word (2.2)

\section{Composite labels}

$\mathrm{Cl}, \mathrm{ACl}, \mathrm{CCl}, \mathrm{NCl}$ and $\mathrm{RCl}$ combine with $\mathrm{i}$, ing, en to form composite labels for non-finite clause types:

Cli Infinitive clause

Cling - ING clause

Clen -EN clause

$\mathrm{V}$ and $\mathrm{v}$ combine with $\mathrm{o}, \mathrm{s}$, ed, i, ing, en to form composite labels for finite and non-finite verb forms:

$\left.\begin{array}{ll}\text { Vo } & \text { Present tense or base form } \\ \text { Vs } & \text { Third person singular present tense form } \\ \text { Ved } & \text { Past tense form }\end{array}\right\}(3.2 .2,3.3 .6,4.5 .1)$

$\mathrm{Vi} \quad$ Infinitive (4.5.1)

Ving - ING or present participle

Ven -EN or past participle

\section{Specialised labels}

The following symbols are used, mainly in 4.5, for subclasses of $A u x$ and $\mathrm{v}$ :

Aux: Mod Modality (4.5)

Pass Passive voice (4.5)

Perf Perfective aspect

Prog Progressive aspect (4.5) v: be Primary verb to be (3.3.6;

4.5)

do 'Dummy' verb do (4.5;

4.5.2)

hv Primary verb to have

$(3.3 .6 ; 4.5)$

m Modal verb $(3.3 .6 ; 4.5)$ 
The following particles (3.3.8) are used as their own labels:

$\begin{array}{lll}\text { it } \quad \begin{array}{c}\text { 'empty' subject it } \\ (7.7 .1)\end{array} & \begin{array}{l}\text { there } \\ \text { not }\end{array} & \begin{array}{l}\text { 'existential' there (7.7.2) } \\ \text { infinitive marker (3.4) }\end{array} \\ \text { not } & \text { to negation (3.4) }\end{array}$

\section{Bracketing}

[ ] around clauses

() around phrases

- separates word constituents

\langle\rangle encloses two or more coordinates (6.7)

\{\} encloses an optional constituent (2.4.4)

links interrupted constituents of a unit (5.1.3): e.g. (Is (he) kidding?)

\section{Labelling}

The symbol * (asterisk) precedes an ungrammatical construction (2.5.1). Form labels (2.5.1) have an initial capital for open classes, lower case for closed classes. They are written as subscripts before the opening bracket or before the word: NP(pnYou!).

Function labels (2.5.2) are in italics in the text; when writing them, use underlining: e.g. use $\underline{\mathrm{S}}$ for $S$. They are written as superscripts before the opening bracket or before the word: ${ }^{V o c}$ ( ${ }^{H}$ You!).

Function plus form labels $(3.2 .1,3.3 .8)$ : the function label is written above the form label; ${ }_{\mathrm{NP}}^{\operatorname{Voc}}\left(\mathrm{pn}_{\mathrm{pn}}^{H}\right.$ You!).

\section{Skeleton analysis (6.6)}

$$
\text { above a directly subordinated constituent }(6.5 .1,6.6)
$$

above an indirectly subordinated constituent $(6.5 .2,6.6)$

The symbol + (plus) stands for the coordinating conjunction in linked coordination (6.7)

The comma is used between coordinates in unlinked coordination (6.7.1)

Tree diagrams (2.3.2)

See 5.9 on how to build up a fully labelled tree diagram. 